\title{
Pensions on divorce
}

Received (in revised form): 1st December, 1999

\section{Richard Evans}

is a senior solicitor at Rowe \& Maw. He has specialised in pensions law since qualifying in 1992. He has advised on major projects involving the merger, reorganisation and winding-up of occupational pension schemes. He also acts as day-to-day adviser to a number of large schemes. In 1996/97, Richard was seconded to the National Association of Pension Funds, where he was involved in consultation on Regulations under the Pensions Act, and drafted guides to the new legislation. He is an Associate of the Pensions Management Institute.

Abstract This paper looks at recent changes to the ways in which pensions can be dealt with on divorce in England and Wales, and at further changes which are now proposed. Under the Pensions Act 1995, the Courts were given power to 'earmark' benefits, but earmarking has a number of drawbacks. The Welfare Reform and Pensions Act 1999 will introduce a further option - 'pension sharing' - which is generally felt to be more satisfactory.

Keywords: divorce; offsetting; earmarking; pension sharing

\section{Background}

The spouse of a pension scheme member will expect to benefit from the scheme in a number of ways. ${ }^{1}$ While the member is alive, she may benefit indirectly from his pension. On the member's death, she may benefit in her own right. She may be entitled to a widow's pension under the terms of the scheme. She may also be eligible for a lump sum if the member dies in service under an occupational scheme.

Unless suitable provision is made by the Courts, the spouse will lose these potential benefits on divorce. She will no longer expect to share in the member's pension. She may cease to be eligible for any lump sum benefit on the member's death and, by definition, she will not be able to qualify for a widow's pension. A minority of occupational schemes allow pensions to be paid to dependants rather than widows, but an ex-spouse may not be able to show the necessary level of dependency, particularly if there has been a 'clean break' on divorce. Even where a scheme allows a dependant's pension to be paid, the trustees may not be inclined to allocate it to an ex-spouse if the member has a new wife, or children under 18.

\section{The position pre-Pensions Act - offsetting}

Until the Pensions Act 1995 came into force, the Courts had only very limited powers as to pensions on divorce. A Court might order one party to pay maintenance or a lump sum to the other, but it was not normally possible to rewrite the terms of the pension scheme, or to make orders against the scheme's trustees or managers.

In many divorces, the question of pensions was overlooked. The Matrimonial Causes Act 1973 did not expressly require Courts to take account of pensions, and the potential value of the member's benefits was not always considered by the parties' solicitors. (In practice, the terms of a divorce are 
usually negotiated between the solicitors, with the Court giving formal approval to an order which has been agreed by the divorcing couple.)

Where specifically addressed, the pensions problem was usually dealt with by means of 'offsetting'. The member would use other assets to compensate the spouse for loss of pension expectation. For example, the member might pay the spouse a lump sum, or might transfer property to her. But this option was not available where, as in many cases, the member had no significant assets other than his pension rights.

\section{The Pensions Act - earmarking}

\section{Overview}

The Pensions Act made significant changes to the law with effect from 1 st August, 1996 (though divorces begun before 1st July, 1996 were unaffected). Section 166 of the Pensions Act amended the Matrimonial Causes Act in two key ways. First, the Courts were expressly required to take account of pensions on divorce. Secondly, Courts were given a new way of dealing with pensions. Offsetting would still be an option, but Courts would also be able to 'earmark' the member's pension benefits, so that they became payable to the spouse. These changes applied in respect of occupational schemes, personal schemes, retirement annuity contracts and certain other annuities and insurance policies giving effect to pension rights.

\section{Requirement to take account of pensions}

The requirement for Courts to take account of pensions is set out in Section 25B(1) of the Matrimonial Causes Act. When considering the financial resources of the member, the Court must now take account of 'any benefits under a pension scheme which [he] has or is likely to have' (note that there are two limbs to this provision). Conversely, when assessing the loss which the spouse will suffer as a result of the divorce, the Court is directed to consider 'any benefits under a pension scheme which [she] will lose the chance of acquiring'.

The Divorce etc (Pensions) Regulations 1996 (the Divorce Regulations) specify that the value of accrued rights of active members and deferred pensioners will be the 'cash equivalent' of those rights. ${ }^{2}$ The effective date of the valuation can be chosen by the Court, provided it does not fall before the start of the divorce proceedings. In practice, the parties will normally rely on figures supplied by the pension scheme (see below).

The Divorce Regulations do not lay down rules as to the valuation of pensions in payment, or benefits which the member is 'likely to have'. This last point is significant, because it leaves scope for argument about what value, if any, should be put on any prospective benefits not reflected in an active member's cash equivalent. If benefits under the scheme are salary-related and the member is likely to receive substantial pay rises, the spouse may argue that the cash equivalent (which makes no allowance for future increases) does not fairly reflect the expected benefits. The spouse may raise a similar point if the member is expected to receive a valuable discretionary benefit which is not reflected in the cash equivalent - for example, favourable terms as to early retirement.

\section{Valuation requests}

The requirement for Courts to take account of pensions is backed up by new procedural rules for divorce cases. The 
member must now supply the spouse with all information which he possesses as to his pension benefits, including the most recent cash equivalent valuation (if any). ${ }^{3}$

The Divorce Regulations allow a member to request a suitable valuation for this purpose - and the Court can order him to submit a request if necessary. ${ }^{4}$ The trustees or managers of the scheme can choose the effective date of the valuation, but it must be within a period of three months beginning with the date of the member's request. The valuation must then be supplied to the member within ten days of the effective date. If the member has asked, the trustees or managers must say what proportion of the cash equivalent is attributable to any pension potentially payable to the spouse on the member's death. $^{5}$

There is a provision which allows trustees or managers to pass on to the member the cost of supplying information. However, the cost can be passed on only to the extent that it exceeds the cost which would have been incurred if the member had requested a valuation under the normal disclosure legislation. ${ }^{6}$ There is nothing which would allow the trustees or managers to recover costs by means of a deduction from the member's benefits.

\section{Earmarking orders}

The Courts' powers to make earmarking orders are set out in Sections 25B and $25 \mathrm{C}$ of the Matrimonial Causes Act. In essence, a Court can do any or all of three things.

First, the Court may require the member to pay maintenance to the spouse from his pension. Where a maintenance order is made, the Court may order the pension scheme to pay part or all of the pension directly to the spouse.
Secondly, the Court may require the member to exchange pension for a lump sum on retirement, where this is an option under the pension scheme. The member may then be ordered to pay part or all of the lump sum to the spouse. Where such an order is made, the Court may direct the pension scheme to make payment to the spouse rather than the member.

The third option relates to any lump sum benefit payable on the member's death. The Court may require part or all of any such lump sum to be paid to the spouse if the member dies. Any discretion of the trustees or the member as to the recipient will be overridden.

Where the spouse is seeking an earmarking order, the Court's procedural rules require her solicitors to serve formal notice on the trustees or managers of the pension scheme. In practice, a draft of the proposed order will usually be supplied. The rules then give scope for the trustees or managers to object to the order, to file an affidavit setting out their position, or even to appear before the Court. In practice, trustees and managers tend to object to orders only where the solicitors have misunderstood the law or the terms of the relevant scheme.

The Divorce Regulations allow trustees or managers to recover a sum from the member in respect of administrative expenses which they may reasonably incur as a result of the earmarking order. The Court can decide the amount which can be recovered if it cannot be agreed.

\section{Transfers and other events affecting benefits}

The making of an earmarking order will not prevent the member from transferring his benefits to another 
pension scheme. However, Section 25D of the Matrimonial Causes Act effectively provides that, where a transfer is made in respect of all the member's benefits, the receiving scheme will become subject to the order.

For this to happen, the transferring scheme must give formal notice both to the receiving scheme and to the spouse, not more than 14 days after the transfer. The receiving scheme must be given a copy of the earmarking order, while the spouse must receive an explanation about the transfer and the effects of Section 25D.

Provided these requirements are met, the earmarking order will cease to apply to the transferring scheme, taking effect against the receiving scheme instead.

A scheme which is subject to an earmarking order will also have to comply with formal notice requirements if 'an event has occurred which is likely to result in a significant reduction in the benefits payable under the scheme' (though thankfully a fall in investment values due to market conditions can be ignored for this purpose). ${ }^{7}$ Within 14 days of the event, the scheme must tell the spouse what has happened, and must give an estimate as to the reduction in benefits. If the reduction arises because the member has transferred some, but not all, of his benefits to another scheme, details of the receiving scheme must be supplied.

The spouse herself will have certain disclosure obligations. ${ }^{8}$ In particular, she will have to notify the scheme if her address changes, or if the earmarking order ceases to have effect (a maintenance order will automatically cease to have effect if she remarries). If she fails to notify the scheme of a change of address and, as a result, the scheme cannot make payment to her, liability can be discharged by making payment to the member.

\section{Drawbacks to earmarking}

An earmarking order effectively diverts part or all of the member's benefits, so that they are paid directly to the spouse. There are obvious drawbacks to this approach.

Perhaps the most significant point is that the spouse will receive the earmarked element only if and when the member's benefits become payable. Where an earmarking order is made over the member's pension, the spouse will receive nothing until the member retires (and the Court cannot order him to retire at a particular date). In any event, the spouse's income from the pension will cease when the member dies - it is not payable to her for her life.

A further problem is that an earmarking order over pension will cease to apply if the spouse remarries. Remarriage deprives the spouse of the income she was expecting to provide her with security in old age.

In short, earmarking is inconsistent with the idea that divorcing couples should try to achieve a 'clean break'. Earmarking is also unattractive for pension schemes, in that it leaves them with a long-term administrative burden. A scheme will have to hold details of the earmarking order and the spouse for the period between the divorce and the date when benefits become payable. In an extreme case, that period could be as long as 40 years.

\section{The Welfare Reform and Pensions Act - pension sharing}

\section{Overview}

The Government is planning to extend the powers of the Courts so that, as well as offsetting and earmarking, there will be a new option - 'pension splitting' or 'sharing'. The idea is to allow a Court to divide up benefits when the divorce 
takes place: the member's entitlement is debited by a specified amount, which is then used to give the spouse benefits in her own right.

Provisions about pension sharing are included in the Welfare Reform and Pensions Act 1999. The Act will be supplemented by regulations in due course - a consultation draft may be available by the end of 1999 . The Government aims to bring the pension sharing provisions into force by April 2001 now seem possible. Divorces which begin before the implementation date will not be covered.

The new provisions will apply to occupational schemes, personal schemes, retirement annuity contracts and certain other annuities and insurance policies giving effect to pension rights. The provisions will also apply to benefits under the State Earnings Related Pension Scheme, though not to the basic State pension.

\section{Pension sharing orders}

The Courts' power to make pension sharing orders will be set out in a new Section 24B of the Matrimonial Causes Act. A pension sharing order will provide for the member's rights under the relevant pension scheme to be subject to sharing for the benefit of the spouse, and will specify the percentage value which is to be transferred.

The member's rights will then become subject to a debit of 'the appropriate amount', while the spouse will become entitled to a credit of the same amount under the pension scheme. 'The appropriate amount' will be the specified percentage applied to the cash equivalent of the member's benefits. For this purpose, benefits are determined as at the date when the order is made, and an active member of an occupational scheme is assumed to have left pensionable service immediately before that date. The trustees or managers of the pension scheme can decide the date on which the cash equivalent of the benefits is calculated, provided the date is within the period allowed for implementing the order (see below). ${ }^{9}$

\section{Member's benefits - the debit}

The effect of the debit will be to reduce the member's 'qualifying benefits' by the percentage specified in the order. 'Qualifying benefits' are benefits taken into account for the purpose of the cash equivalent calculation. ${ }^{10}$ It follows that, for an active member of an occupational scheme, a debit will not affect future service benefits. Instead, it will act as a reduction in the short service benefit to which the member would have been entitled if he had left service at the date of the order. Some commentators have described the debit as 'a negative deferred pension'.

The legislation provides for the debit to apply to 'each of' the qualifying benefits, but does not say what constitutes a separate benefit for this purpose. It seems that, where a member is entitled to a guaranteed minimum pension or protected rights, plus an excess on top, each of those elements will have to be reduced. However, there are still a number of grey areas, and a reduction could be subject to challenge unless it is clearly authorised by the legislation. For example, a member of an occupational scheme could bring a complaint based on Section 67 of the Pensions Act if he feels his benefits have been reduced any further than the legislation requires. ${ }^{11}$

There has been considerable debate about the extent to which a member should be able to rebuild his benefits after they have been reduced. The 
Government initially said that, when assessing whether a member's benefits were within the Inland Revenue limits which apply to approved schemes, he would be treated as though still entitled to the part which had been debited. Such an approach would restrict the scope for rebuilding, and on 18th March, 1999 the Government announced a limited concession. A member on a 'moderate income' - up to one quarter of the statutory cap on pensionable earnings - will not have to bring the debited part into account for Inland Revenue limits purposes. In practice, the concession may not be as helpful as it sounds. Members on moderate incomes ( $£ 22,650$ on current figures) will often be those who can least afford to rebuild. All members will in any case be subject to the normal Inland Revenue limit on their contributions (15 per cent per year), which will restrict the scope for rebuilding, particularly where a debit is made shortly before retirement.

\section{Spouse's benefits - the credit}

After an order is made in respect of a pension scheme, the trustees or managers will have four months in which to give effect to the credit for the spouse. If they fail to meet the four-month deadline, they will have to notify the Occupational Pensions Regulatory Authority (OPRA). OPRA will have power to impose financial penalties. ${ }^{12}$

A credit must be effected in one of two ways: an internal transfer, whereby rights are created for the spouse under the member's pension scheme; or an external transfer, whereby a transfer is made to another suitable scheme on the spouse's behalf. ${ }^{13}$

It seems that personal schemes and funded occupational schemes will normally be obliged to offer external transfers, but will not have to allow internal transfers. Unfunded schemes will be able to require spouses to accept internal transfers.

There will be various terms and conditions as to the benefits which a spouse is given in return for an internal transfer. The spouse must be able to take payment of the benefits at a specified age between 60 and 65 . Her pension will be subject to requirements as to increases in payment, as the member's pension would be under the Pensions Act. The trustees or managers will have to disclose certain information to her. Moreover, it seems she will be able to demand a cash equivalent-type transfer, in much the same way that the member could have done. $^{14}$

If the member's benefits include contracted-out rights (guaranteed minimum pension, Section 9(2B) rights or protected rights), further requirements will apply, whether on an internal transfer or an external one. The part of the spouse's benefits which is derived from the member's contracted-out rights will be known as 'safeguarded rights'. Regulations will set out special restrictions as to safeguarded rights - no doubt similar to the restrictions which apply to contracted-out rights. ${ }^{15}$

\section{Costs}

A pension scheme which becomes subject to a sharing order will be able to recover costs from the parties to the divorce. The order may specify the amounts or proportions to be borne by each party. If the order is silent, the costs will be borne by the member. ${ }^{16}$

The Government does not intend to impose any fixed ceiling on the costs that can be recovered. However, costs will have to be 'reasonable'. Industry bodies have said they would be willing to draw up a table showing the costs 
which could be passed on in routine cases. In previous consultation, the Government indicated that costs might be $£ 650-£ 1,200$ for an internal transfer and $£ 200-\mathcal{E}^{3} 350$ for an external one. The Pensions Ombudsman will be able to adjudicate in cases where there are disputes about costs.

\section{Conclusion}

The Government has not yet issued Regulations under the Welfare Reform and Pensions Act, and there is still some uncertainty about how pension sharing orders will work in practice.

Nevertheless, it is clear that pension sharing will often be more satisfactory than earmarking. In a typical pension-sharing case, the member's pension scheme will make a transfer to another scheme on the spouse's behalf. Following the transfer, the spouse will be entitled to benefits in her own right, rather than just a part of the member's benefits when payable; and the member's pension scheme will have no further obligation in respect of the spouse. For these reasons, the idea of pension sharing has met with a warm reception, not just among family lawyers but also within the pensions industry.

\section{Postscript}

As envisaged in this paper, the Department of Social Security has now produced draft Regulations under the Welfare Reform and Pensions Act 1999. The draft Regulations deal with the mechanics of pension sharing, including the provision of information to members and spouses, the calculation of cash equivalents, the means by which effect can be given to credits, the terms which apply to 'safeguarded rights' and other benefits derived from credits, and the recovery of costs by pension schemes. The draft Regulations were published on 15 December 1999, and will be subjected to consultation until 14th February 2000.

\section{References}

1 For simplicity, this paper makes certain assumptions about the pension arrangements of married couples. It assumes that the husband ('the member') will belong to an occupational or personal pension scheme, and that the wife ('the spouse') will not.

2 Regulation 3. The Government plans to issue replacement regulations shortly, but the basic principles are likely to remain as set out in the Divorce etc. (Pensions) Regulations 1996.

3 Rule 2.70(1) of the Family Proceedings Rules 1991, as amended by the Family Proceedings (Amendments) (No. 2) Rules 1996.

4 Regulation 4; Rule 2.70(2) of the Family Proceedings Rules 1991, as amended.

5 Regulation 5 of the Divorce Regulations.

6 Section 93A(1) of the Pension Schemes Act 1993, the Occupational Pension Schemes (Transfer Values) Regulations 1996 or the Personal Pension Schemes (Disclosure of Information) Regulations 1987, under which a member is entitled to receive one valuation every 12 months.

7 Regulation 7 of the Divorce Regulations.

8 Regulation 8 of the Divorce Regulations.

9 Section 29 of the Welfare Reform and Pensions Act (WR \& P Act).

10 Section 31 of the WR \& P Act.

11 Section 67 restricts the scope for amendments which affect members' entitlements or accrued rights.

12 Section 34 of the WR \& P Act.

13 Schedule 5 of the WR \& P Act.

14 Sections 37 and 40 of the WR \& P Act.

15 Section 31 of the WR \& P Act.

16 Section 41 of the WR \& P Act. 